\title{
Analysis of Genetic Impurity of An Original Cultivar Duku (Lansium parasiticum (Osbeck.) K.C. Sahni \& Bennet.), from Jambi, Indonesia Using ITS and MatK Gene
}

\author{
Syamsuardi ${ }^{1 *}$, Chairul ${ }^{1}$, Pinta Murni ${ }^{2}$ \\ ${ }^{1}$ Department of Biology, Faculty of Math. And Nat. Sciences, Universitas Andalas, Limau Manis, Padang, Indonesia \\ ${ }^{2}$ Department of Biology, of Math. And Nat. Sciences, Universitas Jambi, Indonesia \\ *Corresponding Author: Email ID: anes82@gmail.com
}

\begin{abstract}
Duku Kumpeh is a original cultivar of Duku (Lansium parasiticum) from Kumpeh a local village in the Jambi, Indonesia. The understanding about genetic information is very important for sustainability used of this prospoctive germplasm of tropical fruit. Identification molecular is very essential to distinguish duku kumpeh with other cultivars of duku in Indonesia. Molecular characteristic of sixteen accessions of Duku Kumpeh were clarified using ITS and MatK gene. DNA from sixteen accessions duku from Jambi were extracted using Genomic KIT plant and amplified them using primer of ITS and MatK gene. The results of amplification DNA samples using both of primer ITS and MatK gene indicated that all of fifteen samples were effectively amplified. So this both of two genes are potential to use for barcoding DNA Duku. Six haplotype of ITS gene and eleven haplotype of MatK gene were identified. The accessions from kumpeh were have different haplotypes. There were genetic impurity in accessions of duku kumpeh. Genetic study and selection of duku kumpeh accessions with superior quality and similar genetic composition were needed in the future.
\end{abstract}

Keywords-barcoding DNA, duku, ITS, Haplotype, Lansium parasiticum, MatK.

\section{INTRODUCTION}

Duku (Lansium parasiticum (Osbeck) K.C.Sahni \& Bennet) is a unique and potential tropical fruit belonging to the Meliaceae (Mahogany family), but it is not quite planted on a plantation scale. Most of the fruits seen in markets are being resulted from trees in village plantation. This plants have been cultivated for long period, and Ma Huan, a the Chinese traveler have been being remarked it in year 1413 [1].

The duku trees were distributed mainly in South East Asia regions particularly Indonesia in Southern part of Sumatra, Philippines, Southern part of Thailand and
Peninsular Malaysia [1]. This tropical plant is not only important as a edible fruit and widely consumed fresh for dessert but also it can also be utilized in cosmetics due to its extract has antioxidant property as well as moisturizing and almost no effects with a good safety profile [2]. The people used this plants for treatment of intestinal problems, and malaria, because of its fruit, seed and bark, have specific chemical constituent such as: andirobin derivates, methyl-angolensates, exicanolides, anazadiradione, onoceranoids and dukunolides, lansionic acid. [3]. There were eleven different synonym name of duku, thus make confuse in recognozing the taxonomic position. Lansium parasiticum (Osbeck) K.C.Sahni \& Bennet was the valid name for duku and accepted for scientific purposes [4]. Although it was not right scientific name, Lansium domesticum Corr. was often referred as the Latin name of duku. Now, duku and its related were recognizable into three main groups i.e. duku, langsat or bidjitan and kokosan. Duku has small ellipsoid and pale yellow fruits, without latex and flowers small in diameter; langsat or bidjitan possesses a ellipsoid large fruit, glabrescent, fruits with pale yellow pericarp, larger flowers and stem contain slight latex; kokosan has the biggest flowers but its fruits is smaller, globose, with orange-yellow tough pericarp, and stem produce latex and most pubescent leaves [1]. The morphological appearance of the varieties was almost similar, so the varieties were not easy to recognize.

Based on the molecular characteristic, duku was different taxonomic position with kokosan and langsat group [5]. Related to production of indigenous duku of Sumatra, duku kumpeh was been cultivated in Jambi as the source of income for fruit farmers. Hence, now Jambi area was the second largest duku producer in Indonesia.

Related to the producing of tropical fruit duku, there are five centers production of duku In Jambi that are Kumpeh, Sorolangun, Tebo, Selat and Bangko. Kumpeh 
area produce of the best quality duku that export to other areas in Indonesia, especially to South Sumatra region, i.e. Palembang. In this area, duku from Kumpeh is known as 'duku Palembang'. To produce the best quality of duku, selection of seedling resources were required. However, in the present, for propagation purpose, the seedling cannot be identified easily. So, the source of seedling and characteristics of the duku was essential to clarify.

From morphological characterization, It is difficult to know whether the duku from kumpeh or from others places such as Sorolangun, Tebo, Selat and Bangko. Molecular examination with the ISSR and RAPD markers also obtained uniform bands [6], so there is difficulties in distinguishing duku between accessions from Jambi area. Therefore, it is crucial to use more accurate molecular markers to identify, and clarify their relationship as an effort to sustainable utilization of the prospective indigenous duku from Jambi region. DNA barcode was the new marker that uses a standardized genomic DNA sequences as a barcoding for distinguishing species more rapidly and efficiently [7].

For this reason technique barcoding DNA has been applied for analysis plant communities [8]. Application of barcode was not only the most trusty and cost efficient alternative methods for identification of species and useful for clarification the source of germplasm and similarity between the taxonomic level [9] [10], but also useful method for genotype characterization and allows a high precision to know genetic relationship between infraspesific taxa such as cultivar level [11] [12].

Based on these facts, we used ITS and MatK sequence as markers for detection genetic impurity and relationship of some accessions duku original from Kumpeh, Jambi, Indonesia.

\section{MATERIAL AND METHODS}

Total fifteen samples of duku were gatherred from five center localities for duku (Lansium parasiticum ) production of in Jambi area, there were Bangko (BK04, BK 10 and BK 19 ), Tebo (TB 03 ,TB 11 , and TB 14 ), Kumpeh (KP15, KP17 and KP25), Selat (SL16, SL17 and SL 18), and from Sorolangon (SR03, SR 10 and SR 18) represented duku accessions native in Jambi (Figure 1). The young leaves of duku trees were grinded and DNA extraction was performed using CTAB (cetyl trimethyl ammonium bromide ) method [13 ]. The fresh young leaves about $0.1 \mathrm{mg}$ were finely grinded. The resulting DNA isolation were amplified using the primers of two barcode DNA, ITS and MatK.

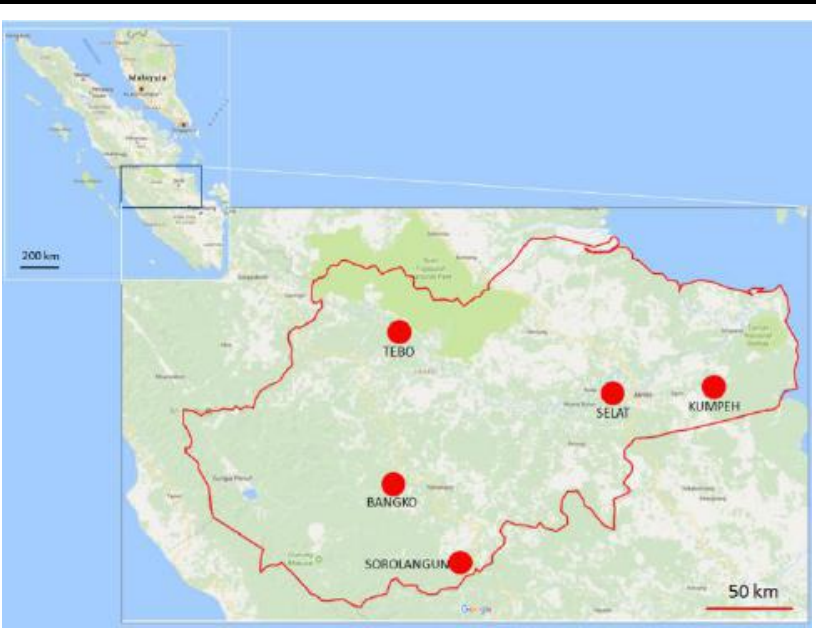

Fig. 1. Sampling sites of original cultivar from Jambi (Modification from:https://www.google.com/maps/placel Jambi, +Indonesia)

This activity was achieved using PCR (Polymerase Chain Reaction ) technique andthe PCR produce was further purified using Mega Quick SpinTM PCR. Purification of DNA fragments was visualized on $1 \%$ agarose gel. Furthermore , $20 \mathrm{ul}$ amplified produces were analyzed at Macrogen Inc. ( Korea) to obtain the sequence of DNA. The sequences DNA were arranged using program BioEdit version 7.0.4. [14] and the program of ClustalX was applied for alignment the homologous sequence [15]. The multiple alignment files were analyzed with MEGA version 6.0 program [16]. Concatenating sequences of the two loci (ITS and MatK ) were arranged by DAMBE Version 6 .4.100 Program [17]. The evolutionary distances between fifteen accessions were analyzed by the $\mathrm{p}$ - distance method [8]. The phylogenetic relationship of fifteen accessions were constructed using the Kimura -2Parameter (K-2-P) model, and Neighbor -Joining (NJ) method [21]. The bootstrapping consensus tree were inferred with 1000 replicates ) to illustrate the evolutionary relationship between the accessions studied [22].

\section{RESULTS AND DISCUSSION}

The results of DNA extraction of fifteen accessions of duku have been done. The samples were collected from five site of producer areas of Duku (Lansium parasiticum ) in Jambi area, i.e. from Bangko (BK04, BK 10 and BK 19), Tebo (TB03, TB11, and TB14), Kumpeh area (KP15, KP17 and KP25), from the Selat (SL 16, SL17 and SL18) and from Sorolangon (SR 03, SR 10 and SR 18 ). For more details, sampling sites were shown in Figure 1. 
Table.1: Primers and their sequences of two barcodes dna (its and matk) that amplified to 15 samples dna of duku.

\begin{tabular}{|l|l|c|}
\hline Primer & Sequence (5'-3') & Reference \\
\hline ITS5-F & GGAAGTAAAAGTCGTAACAAGG & {$[19]$} \\
\hline ITS4-R & TCCTCCGCTTATTGATATGC & {$[20]$} \\
\hline 3F_KIM-F & CGTACAGTACTTTTGTGTTTACGAG & \\
\hline 1R_KIM-R & ACCCAGTCCATCTGGAAATCTTGGTT & \\
\hline
\end{tabular}

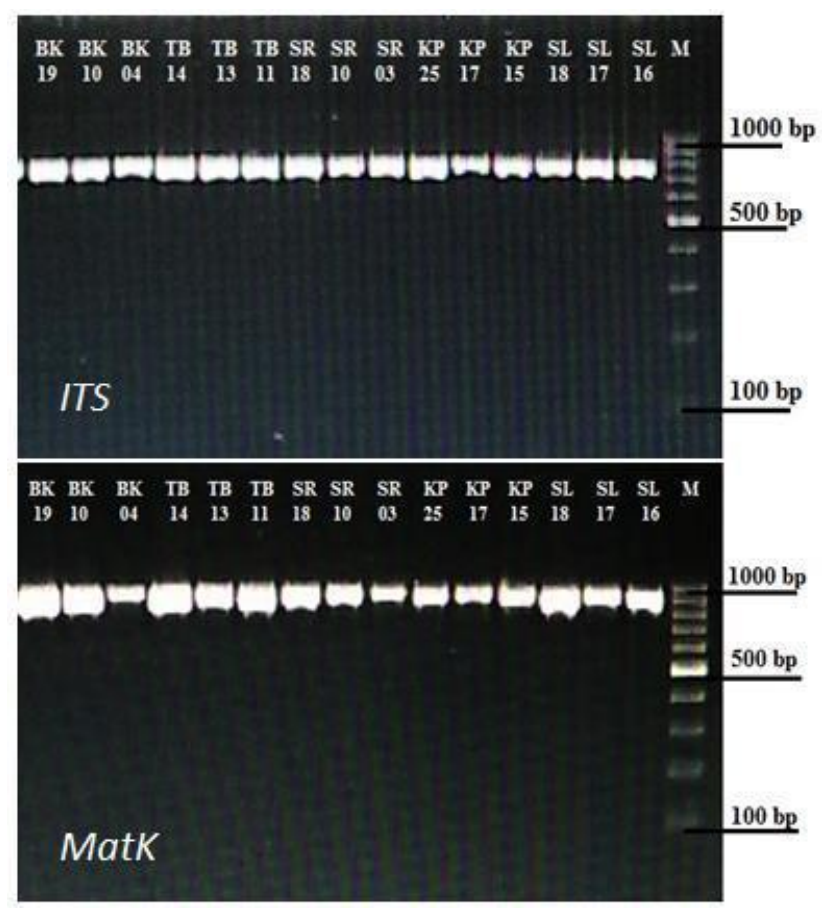

Fig. 2. Profile bands from electrophoresis fifteen accessions studied after amplified by ITS (upper) and Matk (lower)

DNA of fifteen samples of duku accessions from five center production of duku i.e. Bangko (BK04, BK10 dan BK19), Kumpeh (KP15, KP17 dan KP25), Selat (SL16, SL17 dan SL18), Sorolangon (SR03, SR10 dan SR18) danTebo (TB03, TB11, and TB14) by using two primers of ITS gene (Table 1) were successfully amplified that proved by clear bands resulted from electrophoresis of samples after PCR amplification (Figure 2). The sequence length of amplification ITS gene was 800 base pair (bp) that was similar to the reported in Fig cultivars (Castro et al., 2015). Amplification of DNA from fifteen of duku accessions using both ITS and MatK barcode Gene produced the similar results. There were clear bands detected after electrophoresis PCR amplified samples ( Figure 2). The sequence length of all fifteen DNA samples after amplified $( \pm 900 \mathrm{bp})$ was similar to previous reported [11] [23].

Furthermore, analysis haplotype was performed on 16 DNA sequences of samples resulted from amplification using the ITS and MatK gene (Table 2). The result ofanalysis sequences based on the nucleotide single polymorphism pattern, Seventeen haplotypes were identified, seven of them were obtained from ITS gene and 10 of them were detected on sequence from MatK gene. Application of combination of two both of DNA barcoding ITS and PsbA-TrnH were successfully for discriminating the plant populations [24]. In case of application both of MatK and RbcL resulted in lower resolution for clarification of plant populations. In this study, the number haplotypes detected in accessions duku from jambi was very high (17 haplotypes ). This is very important and useful to detect the origin of the accessions. Haplotype 04 (H04) from ITS was detected over nine accessions from five central duku areas (Bangko, BK; Sorolangon, SR, Selat, SL; Kumpeh, KP; and Tebo, TB). The following haplotype H03 from MatK gene was found on four accessions from Bangko, Sorolangon, Selat, Kumpeh, but it was not detected in Tebo (TB). The haplotype diversity among all accessions studied was high $(\mathrm{Hd}=0.74)$. These results was very different to the previous studied applying ISSR and RAPD marker on twenty-one accessions duku from Jambi [6], there was no different between samples analyzed. based on very high haplotype variations, not only between accession at the locality plantation, and even the unique haplotypes detected in some individual accessions from same locality. So, using these two barcodes DNA (ITS and MatK ) were very potential for determination in population genetic analysis, detecting the origin of accessions the unique this tropical fruit.

For precise determination of germplasm sources from duku, it is important to provide a specific sequence that can be used to detect their phylogentic relationship. Thus DNA barcoding was found to be a practical and rapid method for identification not only at species level [25] [26] but also between varieties [27], the populations level [7], ecotypes [28] and inter individuals or accessions from one species.

Furthermore, it is well known that the production center of Duku in Jambi are Bangko, Sorolangon, Selat, Kumpeh and Tebo, with duku from Kumpeh as the best quality variety, but the source of duku accessions in kumpeh is unclear whether they were provided from Kumpeh or other locations. Based on this fact, although with the little number of accessions examined, we tried to detect the purity of duku accessions from each 
production center by using phylogenetic analysis of fifteen accessions from five locations of duku production centers in Jambi.

The Evolutionary divergence between fifteen nucleotide sequences of duku accessions was estimated and then constructed the phyllogenetic relationship. The evolutionary divergence of sequences between fifteen accessions duku from fives localities in Jambi were ranged from 0.00 (BK04 vs KP17, SL16, SR10; KP17 vs SL16, SR10) to 0.029 (SL18 vs BK19) for amplification ITS primer (Table 2, upper matrix). In case of the evolutionary divergence of sequences from amplification MatK primer was lower than by ITS with the value Evolutionary divergence was 0.00 to 0.012 , respectively

Table.2: Seventeen haplotypes from two barcoding dna detected in 16 duku accessions (lansium parasisticum) from jambi.

\begin{tabular}{|c|c|c|c|c|}
\hline No & $\begin{array}{l}\text { Barcoding } \\
\text { DNA }\end{array}$ & Haplotype & Acessions & $\begin{array}{l}\text { Number } \\
\text { Accessions }\end{array}$ \\
\hline 1 & & H01 & SL18, TB11 \& BK04 & 3 \\
\hline 2 & & H02 & BK20 & 1 \\
\hline 3 & & H03 & KP17 & 1 \\
\hline 4 & ITS & H04 & $\begin{array}{l}\text { BK10, SR03, SL16, KP25, SL17, } \\
\text { TB14, TB03, KP15 \& SR18 }\end{array}$ & 9 \\
\hline 5 & & H05 & BK19 & 1 \\
\hline 6 & & H06 & SR10 & 1 \\
\hline 7 & & $\mathrm{H} 01$ & BK20 & 1 \\
\hline 8 & & $\mathrm{H} 02$ & TB11 & 1 \\
\hline 9 & & $\mathrm{H} 03$ & BK04, SL16, KP17 \& SR10 & 4 \\
\hline 10 & & H04 & SL17 \& SR18 & 2 \\
\hline 11 & MatK & H05 & KP15 & 1 \\
\hline 12 & & H06 & SL18 & 1 \\
\hline 13 & & H07 & KP25 & 1 \\
\hline 14 & & H08 & SR03 & 1 \\
\hline 15 & & H09 & BK19 & 1 \\
\hline 16 & & H010 & TB13 & 1 \\
\hline 17 & & H011 & TB14 & 1 \\
\hline
\end{tabular}

(SR10 vs KP17) (Table 2, lower matrix). This evidence suggested that sequence DNA of duku resulted from amplification by barcode DNA ITS were more variation than those that amplification by barcode DNA MatK Joining method (Figure 4), the bootstrap consensus tree (inferred from 1000 replicates) was done to know evolutionary history of the accessions analyzed. The bootsrap values more than $50 \%$ was considered statistically significant.

There were a total of 1363 positions in the final data set. Evolutionary analysis were conducted in MEGA 6 [16]. Topology of the phyllogenetic tree indicated that the accessions of duku examined were not clustered to their collection sites. This facts showed that duku plantation in five production centers (Bangko, Sorolangon, Selat, Kumpeh and Tebo) had individual trees from various places. The individual trees of duku from kumpeh were not only origin from kumpeh but also from other locations, especially from location of centre production Duku in Jambi. For the optimal use of duku plants, the purity of the seedlings should be sought. Therefore, the clarification genetic identities (haplotype) of duku accession from kumpeh with the superior quality have to study in the future. 
Table..2: The evolutionary Divergence Using Its Gene (Lower Diagonal) And Matk Gene (Upper Diagonal) Between Fifteen Accessions Of Duku From Five Localities In Jambi

\begin{tabular}{ccccccccccccccc}
\hline Accession & BK04 & BK19 & BK20 & KP15 & KP17 & KP25 & SL16 & SL17 & SL18 & SR03 & SR10 & SR18 & TB11 & TB13 \\
\hline BK04 & - & 0.001 & 0.006 & 0.001 & 0.003 & 0.001 & 0.001 & 0.001 & 0.000 & 0.001 & 0.010 & 0.001 & 0.001 & 0.000 \\
BK19 & 0.028 & - & 0.004 & 0.000 & 0.004 & 0.000 & 0.000 & 0.000 & 0.001 & 0.000 & 0.012 & 0.000 & 0.000 & 0.001 \\
BK20 & 0.005 & 0.028 & - & 0.004 & 0.009 & 0.004 & 0.004 & 0.004 & 0.006 & 0.004 & 0.007 & 0.004 & 0.004 & 0.006 \\
KP15 & 0.001 & 0.029 & 0.004 & - & 0.004 & 0.000 & 0.000 & 0.000 & 0.001 & 0.000 & 0.012 & 0.000 & 0.000 & 0.001 \\
KP17 & 0.000 & 0.028 & 0.005 & 0.001 & - & 0.004 & 0.004 & 0.004 & 0.003 & 0.004 & 0.013 & 0.004 & 0.004 & 0.003 \\
KP25 & 0.003 & 0.025 & 0.008 & 0.004 & 0.003 & - & 0.000 & 0.000 & 0.001 & 0.000 & 0.012 & 0.000 & 0.000 & 0.001 \\
SL16 & 0.000 & 0.028 & 0.005 & 0.001 & 0.000 & 0.003 & - & 0.000 & 0.001 & 0.000 & 0.012 & 0.000 & 0.000 & 0.001 \\
SL17 & 0.003 & 0.028 & 0.005 & 0.001 & 0.003 & 0.005 & 0.003 & - & 0.001 & 0.000 & 0.012 & 0.000 & 0.000 & 0.001 \\
SL18 & 0.003 & 0.029 & 0.008 & 0.004 & 0.003 & 0.005 & 0.003 & 0.004 & - & 0.001 & 0.010 & 0.001 & 0.001 & 0.000 \\
SR03 & 0.001 & 0.026 & 0.006 & 0.003 & 0.001 & 0.001 & 0.001 & 0.004 & 0.004 & - & 0.012 & 0.000 & 0.000 & 0.001 \\
SR10 & 0.000 & 0.028 & 0.005 & 0.001 & 0.000 & 0.003 & 0.000 & 0.003 & 0.003 & 0.001 & - & 0.012 & 0.012 & 0.010 \\
SR18 & 0.003 & 0.028 & 0.005 & 0.001 & 0.003 & 0.005 & 0.003 & 0.000 & 0.004 & 0.004 & 0.003 & - & 0.000 & 0.001 \\
TB11 & 0.003 & 0.028 & 0.003 & 0.004 & 0.003 & 0.005 & 0.003 & 0.005 & 0.005 & 0.004 & 0.003 & 0.005 & - & 0.001 \\
TB13 & 0.010 & 0.024 & 0.008 & 0.012 & 0.010 & 0.008 & 0.010 & 0.012 & 0.010 & 0.009 & 0.010 & 0.012 & 0.008 & - \\
TB14 & 0.005 & 0.022 & 0.010 & 0.006 & 0.005 & 0.008 & 0.005 & 0.008 & 0.008 & 0.006 & 0.005 & 0.008 & 0.008 & 0.013 \\
\hline
\end{tabular}

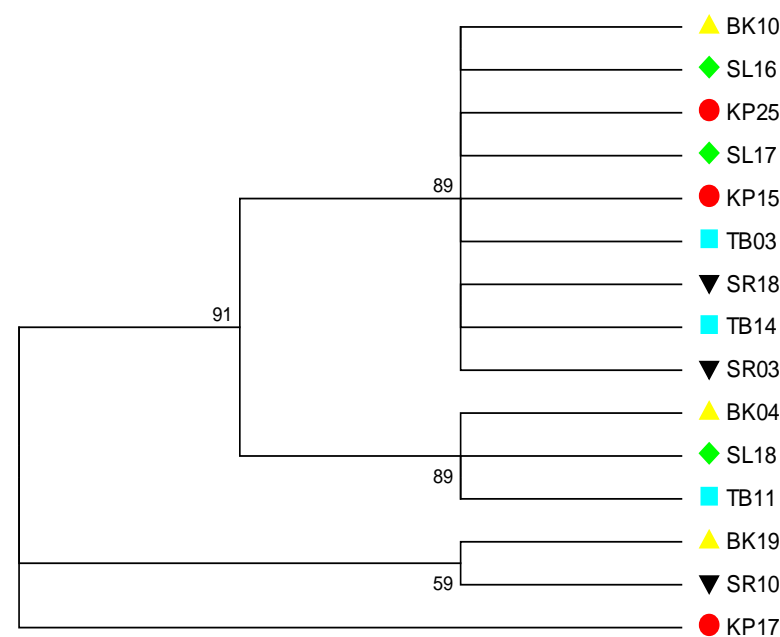

Fig. 2: The phylogenetics tree of fifteen accessions inferred using the Neighbor-Joining method based on ITS + MatK. BK=Bangko, KP=Kumpeh, $S L=$ Selat,$S R=$ Sorolangun and $T B=$ Tebo

Moreover, the high variation of haplotype in other accessions or populations should be maintained as a source of germplasm for genetic conservation of local fruits typical of Jambi.

\section{CONCLUSION}

Amplification of sixteen duku accessions from five locality of duku plantations in Jambi were successful using two barcode DNA ITS and MatK and very effective to detect the genetic polymorphism between accessions . Seventeen characteristics of DNA sequences (haplotypes) were detected using these two barcode DNA. The accessions from kumpeh were not originated from the same sources. the high number unique of haplotype in each accessions or populations was important genetic information for selection germplasm to produce the superior quality and yield and also potential information for genetic conservation of local fruits typical of Jambi, Indonesia.

\section{ACKNOWLEDMENTS}

I would like to thanks Dr. Dewi Imelda, Head of Genetics and Molecular Biology Laboratorium, Dept. of Biology, Fac. of Science, Unversitas Andalas for providing research facilities. Mrs. Ona and Miftahul Jannah for sample preparations. Part of this study supported by Cluster Research Grant of Proffessor Universitas Andalas No. 33/UN.16.17/PP.HGB/LPPM 2017.

\section{REFERENCES}

[1] Nooteboom, H.P., W.J.J.O. de Wilde, D.W. Kirkup, P.F. Stevens, M.J.E. Coode, L.G. Saw. 2017. Flora Malesiana. Lansium domesticum. avalable at http:// portal. cybertaxonomy.org/flora-malesiana.

[2] M. L. Tilaar, W. Wong, A.S. Ranti, S. M. Wasitaatmadja, Surya-ningsih, F.D. Junardy, and Maily. 2008. Review of Lansium domesticum Corrêa and its use in cosmetics Boletín Latinoamericano y del Caribe de Plantas Medicinales Aromáticas 7: 183 - 189.

[3] R. A. Yadav, Pednekar, A. Avalaskar, M. Rathi, Y. Rewachandani. 2015. A comprehensive review on Meliaceae family World J. Pharm. Sci. 3: 15721577.

[4] The Plant List. Version 1.1. 2013. Published on the Internet; http://www.theplantlist.org/ (accessed 1st January).

[5] L. Hanum, R. S. Kasiamdari, Santosa, and Rugayah. 2013. The Phylogenetic Relationship Among Varieties of Lansium domesticum Correa Based on ITS rDNA Sequences. Indonesian Journal of 
Biotechnology 18: 122-132.

[6] P. Murni, Syamsuardi, Nurainas, E. Mansyah and Chairul. 2016. Genetic Variability and out-crossing rate in open pollinated Duku 'Kumpe' (Lansium parasiticum (osbeck) K.C.Sahni \& Bennet.), a Potential Type of Duku from Jambi, Indonesia. Der Pharmacia Lettre 8: 85-191.

[7] L. Meizi, Y. Hui, L. Kun, M. Pei, Z. Whenbin and L. Ping. 2012. Authentification of Illium verum using a DNA Barcode psbA-trnH. Journal of Medicinal Plant Research. 6: 3156-3161.

[8] X.C. Huang, X.Q. Ci, J.G. Conran and J. Li. 2015. Application of DNA barcodes in Asian Tropical trees, A case study from Xishuangbanna Nature Reserve, Southwest China. PLOS ONE 1: 1-17.

[9] Q. Huang, Z. Duan, J. Yang, X. Ma, R. Zhan, H. Xu and W. Chen. 2014. SNP typing for germplasm identification of Amomum villosum Lour based on DNA barcoding markers. PLOS ONE: 1-14,.

[10] R.S. Purty and S. Chatterjee. 2016. DNA barcoding: an effective technique in molecular taxonomy, Austin Journal of Biotechnology \& Bioengineering 3: $1-10$

[11] C. Castro, A. Hernandez, L. Alvarado, D. Flores. 2015. DNA Bar-codes in Fig cultivars (Ficus carica L.) using ITS regions of ribosomal DNA, the $p s b A-t r n H$ Spacer and the matK coding sequence. American Journal of Plant Sciences 6: 95102.

[12] W.J. Kim, Y.Ji, G. Choi, Y. 1987. M. Kang, S. Yang and B.C. Moon, 2016. Molecular identification and phylogenetic analysis of important medicinal plant species in genus Paeonia based on rDNA-ITS, matK, and rbcL DNA barcode sequences, Genetics and Molecular Research 15: 1-15.

[13] J.J. Doyle and J.L. Doyle. 1987. A rapid DNA isolation procedure from small quantities of fresh leaf tissue. Phytochemistry Bulletin 19: 11-15.

[14] T.A. Hall. 1999. BioEdit: a user-friendly biological sequence alignment editor and analysis program for Windows 95/98/NT. Nucl. Acids. Symp. Ser. 41: 95-98.

[15] J. D. Thompson, T.J. Gibson, F. Plewniak, F. Jeanmougin, and D.G. Higgins. 1997. The ClustalX windows interface: flexible strategies for multiple sequence alignment aided by quality analysis tools, Nucleic Acids Research 25: 4876-4882.

[16] K. Tamura, G. Stecher, D. Peterson, A. Filipski, and S. and Kumar. 2013. MEGA6: Molecular Evolutionary Genetics Analysis version 6.0., Molecular Biology and Evolution 30: 2725-2729.
[17] X. Xia. 2017. DAMBE6: New tools for microbial genomics, phylogenetics and molecular evolution, Journal of Heredity 108: 431-437.

[18] M. Nei and S. Kumar. 2000. Molecular Evolution and Phylogenetics. Oxford University Press, New York.

[19] S.Y. Lee, W.L. Ng, M.N. Mahat, M, Nazre R. Mohamed. 2016. DNA Barcoding of the Endangered Aquilaria (Thymelaeaceae) and Its Application in Species Authentication of Agarwood Products Traded in the Market. PLoS ONE 11(4): 1-21.

[20] CBOL Plant Working Group. 2009. A DNA Barcode For Land Plants. Proceedings of the National Academy of Sciences USA 106: 1279412797.

[21] N. Saitou and M. Nei. 1987. The neighbor-joining method: A new method for reconstructing phylogenetic trees. Molecular Biology and Evolution 4: 406-425.

[22] J. Felsenstein. 1985. Confidence limits on phylogenies: An approach using the bootstrap. Evolution 39: 783-791.

[23] W.J. Kress, K.J. Wurdack, E. A. Zimmer, L.A. Weigt and D.H. Janzen. 2005. Use of DNA barcodes to identify flowering plants. PNAS 102(23): 83698374.

[24] Bolson, E. de C. Smid, M. L. Brotto2 and V. S. Pereira. 2015. ITS and trnH-psbA as Efficient DNA Barcodes to Identify Threatened Commercial Woody Angiosperms from Southern Brazilian Atlantic Rainforests. PLOS ONE: 1-18.

[25] H. Schroeder and M. Fladung. 2014. Differentiation of Populus species by chloroplast SNP markers for barcoding and breeding approach. IForest 8: 544546.

[26] M. Bolson, E. De C. Smith, M.L. Brotto, V. SilvaPereira. 2015. ITS and trnH-psbA as efficiency DNA barcodes to identify threatened commercial woody angiosperm from Southern Brazilian Atlantic rainforest, PLOS ONE 2: 1-18.

[27] T. Hidayat, , F.I. Abdullah, C. Koppashamy, A.B. Samad and A. Wagiran. 2012. Molecular identification of Malaysian Pineapple cultivar based on In Ternal Transcribed Spacer Region. APCBEE Procedia 4: 146-151,

[28] W. Heise, W. Babik, D. Kubisz, and L. Kajtoch. 2015. A three marker DNA barcoding approach for ecological studies of xerothermic plants and herbivorous insects from Central Europe. Botanical Journal of Linnean Society 177: 576-592. 